ARTICLE

DOI: 10.1057/s41599-018-0112-x

\title{
Are political representatives more risk-loving than the electorate? Evidence from German federal and state parliaments
}

\author{
Moritz Heß ${ }^{1}$, Christian von Scheve ${ }^{2,3}$, Jürgen Schupp ${ }^{2,3}$, Aiko Wagner ${ }^{4}$ \& Gert G. Wagner ${ }^{3,5,6}$
}

\begin{abstract}
Political representatives frequently make decisions with far-reaching implications for citizens and societies. Most of these decisions are choices in situations in which the probabilities of gains and losses are hard to estimate. Although decision-making is crucial to politics, existing research has hardly ever addressed the political representation of traits that notably influence decision-making. One such trait is risk propensity; that is, an individual's willingness to take risk. Using a unique dataset consisting of representative samples of the German Federal Parliament, four German State Parliaments, and the general German population, the present study investigates the degree to which political representatives' risk propensity resembles their constituents' appetite for risk. Not only descriptive results but even after using matching techniques and controlling for several potentially confounding variables, the study shows that political representatives are significantly more risk loving than the average citizen across several domains of risk taking. The implications of this finding are twofold. First, it points at a representation gap suggesting that politicians tend towards riskier choices than their voters, which not only affects politicians themselves but the entire polity. Second, it suggests a useful 'division of labor' according to which risk-loving politicians are prepared to take risks in exceptional situations, which their constituents would eschew.
\end{abstract}

\footnotetext{
${ }^{1}$ Institute of Gerontology at TU Dortmund University, Dortmund, Germany . ${ }^{2}$ Freie Universität Berlin, Institute of Sociology, Berlin, Germany. ${ }^{3}$ German Institute for Economic Research (DIW Berlin), Berlin, Germany. ${ }^{4}$ Berlin Social Science Center (WZB), Berlin, Germany. ${ }^{5}$ Max Planck Institute for Human Development, Berlin, Germany. ${ }^{6}$ Alexander von Humboldt-Institute for Internet and Society (HIIG), Berlin, Germany. Correspondence and requests for materials should be addressed to M.H. (email: mhess@post.tu-dortmund.de)
} 


\section{Introduction}

olitical representatives frequently have to make decisions under risk in environments where the probabilities of gains and losses are hard to estimate. Historically, many political leaders are known for high risk propensities. They have shown a considerable appetite for risk, for example George Washington crossing the Delaware, Frederik Willem de Klerk ending apartheid in South Africa, and Shinzo Abe restarting Japan's nuclear power plants after the Fukushima meltdown. And when Julius Caesar crossed the Rubicon river, he explicitly mentioned the riskiness of this decision: "Let the die be cast". Caesar highlights the risk, not knowing what the outcome would be. ${ }^{1}$ On the other hand, anecdotal evidence points at political leaders shunning away from risky decisions, for instance U.S. President Barack Obama's politics of compromise and appeasement was criticized as too hesitant. And former German Chancellor Helmut Kohl was infamous for "sitting problems out". However, when at the end of the eighties a window opened for German unification, Chancellor Kohl made risky decisions. Importantly, appetite for risk tends to be normatively framed, in politics, as well as in other fields. For example, former U.S. President Richard M. Nixon once said: "If you take no risks, you will suffer no defeats. But if you take no risks, you win no victories."2 And Mark Zuckerberg, CEO of Facebook, is quoted with: "The biggest risk is not taking any risk. In a world that is changing really quickly, the only strategy that is guaranteed to fail is not taking risks." ${ }^{3}$

Given that in representative democracies small political elites make decisions that have consequences for most members of society, it is an interesting question whether political representatives do - and in fact should - resemble their constituents regarding their risk propensity. Representing constituents is critical for the functioning of democratic political systems, but voters might be much less or substantially more risk seeking than their political representatives. Are political representatives, due to their personal traits, significantly more risk loving than their electorate? Or are their voters willing to take substantially greater risks? And do differences in risk propensity pose a challenge to the principle of democratic representation?

In political theory, representation refers to "the making present in some sense of something which is nevertheless not present literally or in fact" (Pitkin, 1967, p 8f). This understanding of representation emphasizes that political actors (parties or politicians) make present actors other than themselves (Wolff, 2013). The critical distinction between different concepts of representation is in their specification of the phrase "in some sense." Procedural conceptions look at the proportionality of votes and seats. Substantial representation emphasizes correspondence or congruence of political attitudes between representatives and constituents, e.g., regarding political issues or ideologies. A third concept highlights the correspondence of traits like age, ethnicity, and gender for political (descriptive) representation, although not all traits are equally relevant to be represented (Pitkin, 1967; Mansbridge, 2003; Phillips, 1995). "We would not want to complain that the large class of stupid and maleficent people have too few representatives in parliament" (Griffiths and Wollheim, 1960, p 190). Rather, democracies should aim at being descriptively representative regarding a selection of relevant traits (Mansbridge, 1999).

On the one hand, this "representativeness beyond political attitudes" is supposed to safeguard against, for instance, political elites promoting the interests of specific groups or, more generally, making biased decisions. On the other hand, political representatives clearly must assume a role of political leadership. Effective leadership, as is well-established in the business, organization, and political science literature (Derue et al., 2011), goes hand in hand with specific personality traits and competencies that seem to be rather exceptional than widespread in a population, regardless of whether they are based on innate (e.g., genetic traits) or acquired (e.g., education) factors (Hartley, 2014). Moreover, citizens might appreciate politicians having traits and competencies that they themselves lack and that enable political representatives to make proper decisions and implement good policies in complex and uncertain environments. One of these traits shown to be critical for decision-making, in particular under risk and uncertainty, is risk propensity (Kahneman and Tversky, 1979; Sitkins and Weingart, 1995; Yechiam and Ert, 2011; Zuckerman and Kuhlman, 2000).

Regarding political leadership, risk propensity is mainly studied in international politics and presidential decision-making (Mintz and DeRouen, 2010; Kowert and Hermann, 1997; Keller and Foster, 2012). However, given the prevalence of democratic systems around the world, we know surprisingly little about political representatives' risk propensities and how they compare to the risk attitudes of the individuals they represent. Results of existing studies that look at the specific traits and competencies of political representatives are inconclusive at best (Headey, 1974; Hermann, 2014). Although the link between politicians' individual risk attitudes and the practices of collective political decision making in which they are usually involved is far from clear, there are two perspectives offering initial insights.

First, the impact of individual risk preferences on actual decision-making is qualified by contexts in which decisions are made collectively and subjected to debate and joint deliberation, as in most legislative procedures. Although the evidence is inconclusive, studies indicate that collective decisions can be even more risk seeking than the risk attitudes of individual group members would suggest (e.g., Sutter, 2009) and that group decisions approximate rationally optimal decisions more so than individual decisions (Kugler et al., 2012).

Second, when engaging in political decision making on a specific risk object (e.g., peace, climate, public health), it remains unclear what politicians' individual objects at risk (e.g., re-election chances, status, popularity; see Boholm and Corvellec, (2010), for this distinction) and hence the points of reference of individual risk preferences are.

To our knowledge, there are only two studies that have investigated politicians' individual risk propensities in view of political decision making. Martin, (2016) finds that politicians' risk aversion is positively associated with voting for the status quo instead of for a new policy and that this association is mediated by ideology. This study does not really address our research question. Sheffer and colleagues (2017) do so and they demonstrate that politicians show higher levels of risk seeking behavior than non-politicians in a hypothetical choice experiment. However, their study does not use representative samples.

Because the exact links between politicians' risk attitudes and political decision making remain opaque, we take a first step to better understand this link and its underlying mechanisms based on representative samples of members of parliaments. Therefore, we investigate the degree to which political representatives' risk propensity resembles citizens' risk propensity. To this end, we carried out surveys of members of the German Federal Parliament (Deutscher Bundestag) $(N=175)$ and members of selected German State Parliaments (Landtage) $(N=123)$, and use data on the German population available in the German Socio-Economic Panel Study (SOEP).

Risk, political leadership, and occupational selection. Various lines of research establish that risk propensity, i.e. an individual's preference towards risky options, is a significant predictor of 
decision making in different domains (Sitkins and Weingart, 1995; Yechiam and Ert, 2011; Zuckerman and Kuhlman, 2000). Risk attitudes need to be distinguished from risk perceptions that refer to the likelihood that an event or situation is construed as involving risk in the first place (Weber and Milliman, 1997). For example, individuals with a high risk propensity ("risk lovers") are more likely to choose risky alternatives that are associated with potentially high gains but also with higher losses than individuals who are risk-averse (Nosic and Weber, 2010). While the perception of risk is thought to be highly culture specific (Weber and Hsee, 1998), risk attitudes are conceived of as dispositions or personality traits that develop during early socialization (Dohmen et al., 2012; Josef et al., 2016; van den Bos and Hertwig, 2017), notably interacting with specific genetic predispositions for risk seeking or aversion (Roe et al., 2009).

Regarding the question of who becomes a politician or political leader, the literature has not yet established robust patterns of either demographics or specific personality traits (Hermann, 2014). Most recent studies on occupational selection of politicians, however, indicate that although politicians are smarter and have more pronounced leadership skills than the average population, selection on other variables, such as social background, rather follows meritocratic than elitist principles (Dal Bó et al., 2017). Also, personality traits such as dishonesty seem to play a role for self-selecting into politics (Fehrler et al., 2016), although the role of risk attitudes has rarely been studied in this respect.

Given that risk attitudes develop during infancy and adolescence (Dohmen et al., 2011) it seems unlikely that active engagement in politics significantly alters one's risk attitudes in a specific manner. A more obvious mechanism of why politicians' risk attitudes might differ from those of the general population is occupational selection. Theories of occupational selection hold that risk attitudes systematically influence career choice (Sapienza et al., 2009; Bonin et al., 2007). Risk-averse individuals are likely to choose less risky occupations and vice versa. For example, employees in the public sector who often are tenured civil servants have, on average, comparably low risk propensities, while entrepreneurs and the self-employed are known for having high risk propensities (Brown et al., 2011; Caliendo et al., 2010).

Politics is an occupation that involves risks in various respects. First, and regarding political decision-making, countless decision problems are characterized not only by risk, but by fundamental uncertainty, such as those regarding foreign affairs, economic policies, welfare reforms, or environmental protection (Weinberg, 1972; Boettcher, 2004; Levy, 2003, Mercer, 2005; Kam, 2012). Second, political representatives are frequently (at least every electoral term) at risk of failing in their job, i.e. of not being reelected. Becoming a professional politician is also risky because politicians have to win elections to party boards and committees while the probability of making it into the political elite is comparably low. Third, becoming a professional politician is costly and bound to personal investments with uncertain outcomes. In most democratic systems, including Germany, to be nominated by one's party for a position in a national or state parliament involves constant competition with political rivals, within and across party lines. Politicians have to climb the ladder within their parties to earn merit and prestige for their nomination. These considerable costs and uncertain outcomes should thus attract individuals with a high appetite for risk. Fourth, a major motivation to seek a job as an elected politician is the prospect of wielding political power, as Max Weber famously put it (1919, p 2): "He who is active in politics strives for power" (see also Winter, 2002). Research shows that individuals in powerful positions are able to make riskier choices than those who are not (Da Silva, 2014; Anderson and Galinsky, 2006), mainly because power is associated with access to resources that can be used to mitigate the negative consequences of a risky choice. Fifth, political leadership has been shown to involve severe health risks given the high probability that elected representatives experience poor health and develop burn-out (Weinberg and Cooper, 2003), which might also speak in favor of the occupational selection hypothesis.

In sum, as an occupational arena, politics is characterized by factors that should attract individuals with a high risk propensity, simultaneously repelling the risk-averse. Therefore, we hypothesize that political representatives have a significantly higher risk propensity compared to the population average and, consequently, are likely to deviate from citizens and voters in the choices that they make when facing a menu of decisions.

\section{Materials and Methods}

To compare political representatives' with constituents' risk attitudes, we use data from two sources. First, we looked at a nationally representative panel of the German population that contains well-established measures of risk attitudes. Second, in contrast to many studies of elite attitudes and personalities that have relied on expert evaluation (cf. Caprara et al., 2003, p 849), we conducted surveys amongst members of the German Federal Parliament and four German State Parliaments with identical risk attitude measures and standard socio-demographics. Using the same survey instruments for both populations - citizenry and political elites - we avoid mixing different modes of data collection.

Sample. Data on risk attitudes are available from the German Socio-Economic Panel (SOEP), a household panel that has been running since 1984 (Wagner et al., 2007; Headey et al., 2010). The panel draws respondents from a nationally representative sample of individuals aged 16 years and older, comprised of approximately 20,000 individuals interviewed annually over the period under consideration. We used data from waves $2009(N=17,825)$ and $2012(N=18,224)$, including only data of potential voters ("constituents"), i.e., respondents aged 18 years or older with German citizenship. We used data from wave 2009 because it is the most recent wave available in which risk attitudes were assessed for various domains. Compared to other waves, the expressed risk propensity in 2009 was unusually low (most likely due to the impact of the financial crisis in 2008/2009, see Table S4), which is why we conduct robustness checks using data from the 2012 wave (with a higher average risk propensity), but for which only the general risk attitude measure (see below) is available. In 2012, the average population risk attitude was 4.8, which is still significantly lower than that of parliament members (mean of 6.4). This holds true for all other waves that we look at; Table S4 in the SI Appendix presents the average general risk attitudes from 2008 to 2012.

To assess political representatives' risk attitudes, we conducted a postal survey of members of the German Federal Parliament (Bundestag) ${ }^{4}$ and four German State Parliaments (Landtage) in 2012, using the same measures used in the SOEP (see SI Appendix for details). At the time of the survey, the Bundestag consisted of 620 members and the four Landtage comprised a total of 512 representatives (149 from Berlin, 88 from Brandenburg, 137 from Lower Saxony, and 138 from Baden-Wuerttemberg). In the Bundestag 175 (28\%), and in the Landtage 123 (24\%), questionnaires were returned (see Table S1 in SI Appendix for details). Using this procedure, we cannot rule out that questionnaires are actually answered by the political representatives' members of staff instead of themselves. We alleviated this problem by explicitly stating the importance of personal answers in the cover letter. To avoid any suspicion of the members of 
parliament that one would abuse the results on risk propensity by party affiliation and hence reduce the willingness to participate in the survey, no question on party affiliation was included in the survey. In consequence, risk attitudes cannot be depicted by political parties.

Measures. Risk attitudes are measured using two different and well-established approaches (Coppola, 2014; Dohmen et al, 2011). The first approach measures respondents' self-reported risk attitudes in general and in the domains of car driving, financial matters, sports and leisure, career, health behavior, as well as faith in other people. Politicians' questionnaires included an additional item on risk attitudes in political decision making (see SI Appendix for details). The second approach measured risk attitudes using a lottery-choice task, in which respondents decide on a portion of a fictive lottery-win to invest, having a 50/50 chance of doubling the invested amount or losing half of it (see SI Appendix). The hypothetical choice task has been validated with actual experimental and paid lotteries and proven to accurately measure individuals' risk attitudes (Headey et al., 2010; Dohmen et al., 2011). Frey et al., (2017) demonstrate that self-reports have more prognostic power than behavioral experiments because the experiments deal-by definition-with highly specific task domains. In addition to risk attitudes, our surveys assessed respondents' age, gender, and education (see SI Appendix for details).

Methods. To test whether political representative differ in their risk attitudes from their voters, we used matching procedures. Matching is the appropriated analytical tool here as we compare a relative small group (political representative, $N=298$ ) with a large one (SOEP respondents, $N>20,000$ ). It can thus be assumed that one exact statistical twin can be found for each political representative on the variables gender, education and age. We chose Coarsened Exact Matching (Iacus et al., 2009; Iacus et al., 2011) as it allowed us to approach the perfect matched sample as closely as possible. Table S2 shows that the political representative and their statistical twins are absolutely identical regarding gender and education and the age differences are very small. With the political representative and their statistical twins we then ran standard linear regression (Table S3). Figure 3 is based on these regressions, showing coarsened exact matching treatment effects (CEM TE) and, thus, the difference between political representative and their voters while controlling for potentially confounding effects through differences in the gender, educational and age compositions of the two groups. As a robustness check we conducted the analysis while restricting the SOEP sample to only those who show a strong interest in politics. Still, it needs to be acknowledged that although coarsened exact matching allows a much stricter testing for group differences than standard regression techniques, its results are still only based on correlations and causality should not be assumed in a straightforward fashion.

\section{Results}

Initial descriptive analyses of political representatives' and constituents' attitudes toward risk (Fig. 1) suggest that German politicians are more risk seeking than the general population in all assessed risk domains. In most domains, members of the Federal Parliament (Bundestag) report being more risk seeking than members of the State Parliaments (Landtage), although the differences are not significant. In addition, no differences were found between East and West German parliaments. A closer look at the risk domains shows that differences between politicians and the general population are most pronounced in the "career" and "faith in other people" domains. In addition, political representatives' risk propensities in the "general risk taking" and

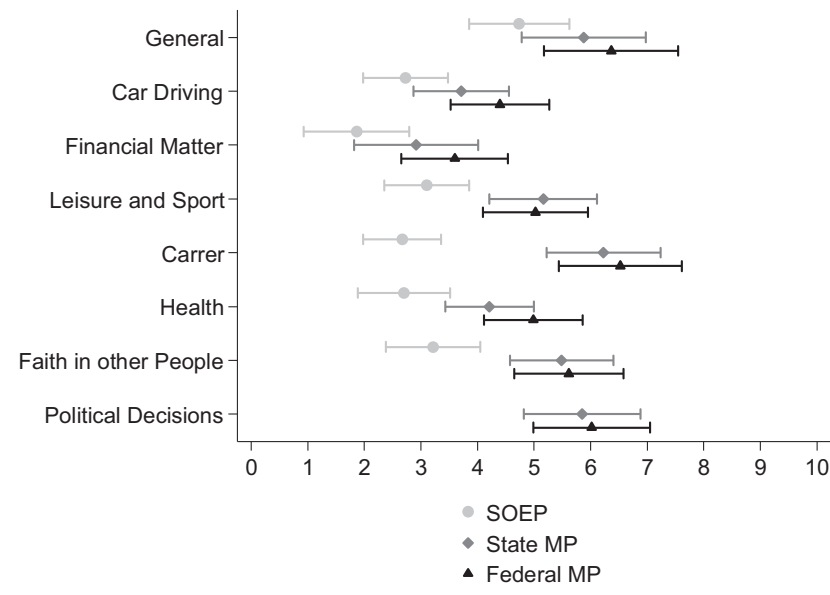

Fig. 1 Average risk attitudes of political representatives (Bundestag and Landtage, $N=298$ ) and the general population (SOEP respondents) in different domains. SOEP data for the "general risks" category are taken from the $2012(N=20,806)$ wave; data for all other domains from 2009 $(N=20,637)$. Depicted are means and $50 \%$ standard deviations

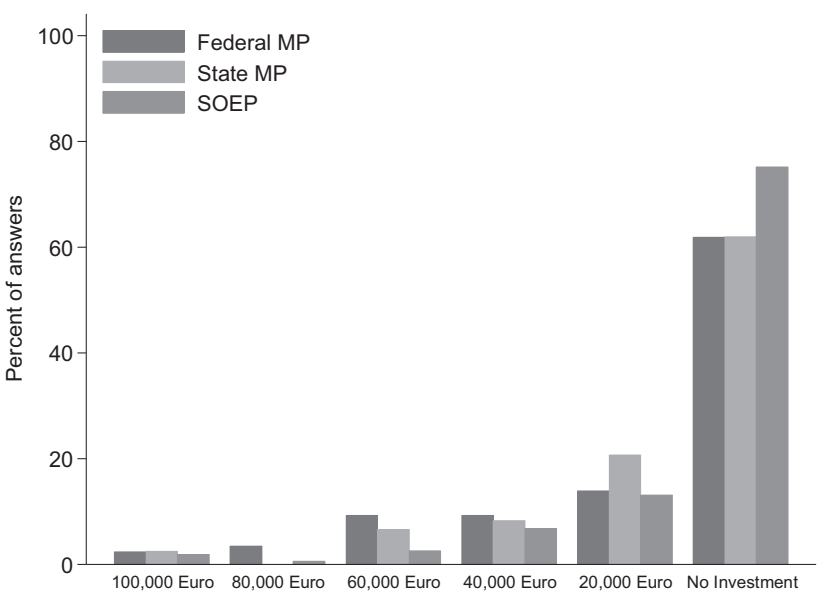

Fig. 2 Percentage of answers how to invest in the lottery-choice task for political representatives (Bundestag and Landtage) and the general population (SOEP respondents in $2009, N=20,615$ )

"political decisions" domains seem exceptionally high. The latter relates to the problem that politicians might choose risky alternatives while citizens would have liked to avoid potential consequence of such choices. This might be particularly relevant in the domain of financial matters. Since politicians report being more risk seeking in these matters, it seems plausible that they are also less risk averse than citizens in budgetary questions. This is supported by a hypothetical choice-task (see Methods section) in which, on average, politicians chose the riskier alternative with the chance of a higher reward, but also with a higher risk of losing the amount invested (Fig. 2).

To further account for the question of how politicians' risk attitude relate to their political decision making behavior, we investigated whether their risk attitudes concerning political matters can in fact be considered part of their general preference for risk. To this end, we conducted a principal-component analysis and results show that politicians' attitudes towards political risk-taking resemble their preference for risk in other domains (see Table S5 in SI Appendix). Hence, politicians who are generally risk loving will also seek risk in political decisions. This is supported by existing research suggesting "that politicians favor 
risk-seeking when faced with policy choices with varying levels of uncertainty-consistently more so than the citizens who elect them" (Sheffer et al., 2017, p 16).

In a third step, we account for potential selection effects resulting from various socio-demographic indicators. Using Coarsened Exact Matching (Iacus et al., 2009; Iacus et al., 2011) without coarsening to ensure a maximum balance and, hence, comparability between treatment (politicians) and control (general population) groups, we compare politicians' risk attitudes with the risk attitudes of those citizens who most closely resemble them with respect to age, gender, and education. The latter two indicators are particularly important since males and the higher educated are known to be more risk seeking (Sapienza et al., 2009; Tsebelis, 2002), with many politicians belonging to both of these groups. Although, socio-demographic variables do explain much of the variation in risk attitudes (Dohmen et al, 2011), it must be acknowledged that not all potential confounding variables could be controlled for.

For the matching procedure, we pool members of the Federal and State Parliaments into one group and conduct two matching analyses. The first included all respondents in the population-based survey, comparing political representatives to average citizens. The second, more conservative, analysis includes only respondents from the population-based survey who report being "very interested" in politics and having a clear party preference (see SI Appendix for details). This way, we can also investigate to what extent political representatives differ from individuals with a pronounced interest in politics (see Table S1 and S2 in SI Appendix for details).

The large number of control units allows for using the stricter k-to-k matching solution (Iacus et al., 2009), resulting in the same absolute number of treated and control individuals. Table S2 shows that the non-matched sample is, on average, less educated than the political representatives are, and that the proportion of men is higher among politicians. We find similar distributions for the politically interested citizen sample, with the exception that they are younger than the sample of political representatives. Including only politicians and their matched counterparts, we used standard linear regressions to estimate the effect of being a politician on risk propensity (see Table S3). Figure 3 illustrates the coarsened exact matching treatment effects, showing that

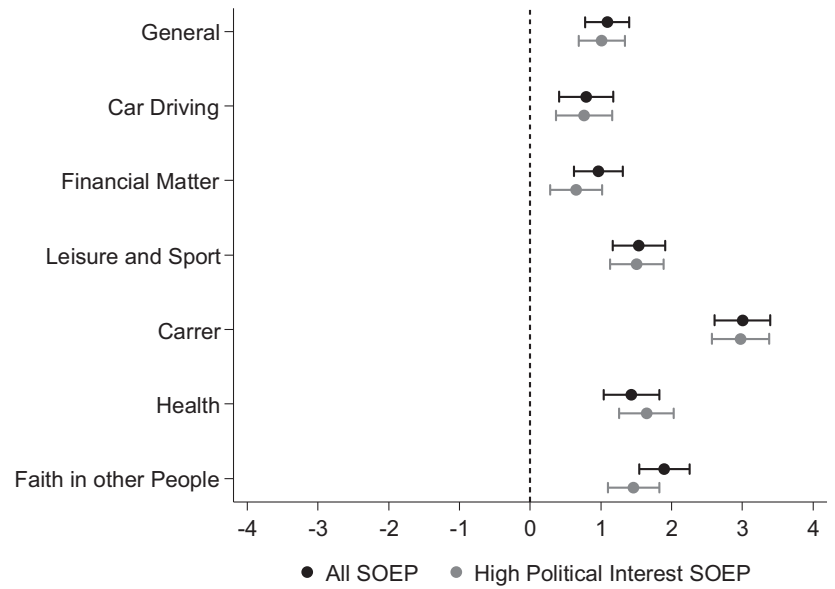

Fig. 3 Coarsened exact matching treatment effects (CEM TE) results for the effect of being a politician on risk attitudes (based on Table S3). Reference groups are the total SOEP sample (black) and only those SOEP respondents with an interest in politics (grey). The relationship is statistically significant when the $99 \%$ confidence interval (gray and black vertical lines) does not overlap the dotted line. SOEP data for the "general risks" category are taken from the 2012 wave; data for all other domains from 2009 even for the matched samples, the difference between politicians and citizens remains significant in all risk domains. Politicians are not only significantly more risk seeking than the average citizen, but also than the politically interested citizens.

\section{Discussion}

Political representatives frequently need to make risky choices in environments where the probabilities of gains and losses are hard to estimate. The willingness to make risky decisions hinges on individuals' risk propensity, and anecdotal evidence describes political representatives as either risk loving or risk averse. Based on representative samples, this research therefore addressed the question whether political representatives, due to their personal traits, are significantly more risk loving than their electorate. If so, they do not represent their constituents' willingness to take risks. We hypothesized that occupational selection is a factor that leads to a disproportionally high number of risk loving individuals amongst political representatives. Comparing risk attitudes of two representative samples of members of the German Federal and State Parliaments with a representative sample of the German population, our study shows that German politicians are, in fact, significantly more risk seeking than the average citizen in all assessed risk domains. This even holds for matched samples and the conservative comparison between politicians and politically interested citizens.

Given that risk attitudes are shaped partly during socialization and partly through genetically inherited factors, it seems that professional politics attracts individuals with a disproportionally high risk propensity. This is supported by the finding that political representatives and citizens differ most notably with respect to risk attitudes in the professional career domain. Occupational selection not only seems to operate regarding selection into the field of professional politics, but also in view of career stages. In Germany, as in many other countries, the way into professional politics is a long and weary path, winding through many political party institutions. Thus, the risk of personal failure and the amount of decision-risks to which political representatives are exposed, are high.

Our results have broad implications for the assessment of the quality of democratic political systems. Political representatives are more risk seeking than their constituents and, hence, might often take risks their voters would not have taken. They might, for example, decide to invest into nuclear energy, while the potentially negative consequences of risky decisions, nuclear meltdowns, affect societies on a global scale. Our results are compatible with a common impression in Western democracies that politicians and governments are often unable to accomplish fundamental reforms (e.g., introducing new taxation schemes or public health insurance). However, this "conservatism", which is often lamented by public choice theorists and political commentators, does not seem to be an indication of risk aversion. Rather, it is the result of the challenges of finding majorities in a world with different interests and many veto players (Tsebelis, 2002). Hence, small changes and reforms are often the only viable political option. They, too, have uncertain outcomes, and thus may nevertheless satisfy politicians' appetite for risk (Thomas et al., 2017).

This raises the question of whether the principle of democratic representation should account for character traits that are relevant to the decision-making process. If this were the case, political representatives might show larger overlap with their voters regarding risk propensity and be less likely to make risky decisions. However, democracies are characterized by sophisticated systems of checks and balances, and far-reaching decisions are rarely made by single individuals. Instead, multiple political 
decision-making institutions negotiate and compromise, thus limiting the role of individual risk propensities on high-impact political issues.

One might thus argue that a certain proneness for making risky decisions in uncertain environments might even be necessary for good politics and societal evolution because-as Max Weber, (1919, p 27) argued - "Politics is a strong and slow boring of hard boards". Similar to firms and businesses, democratic systems might rely on individuals who are ready to take greater risks than the median voter and that this "division of labor" between risk seeking politicians and more risk averse voters might be a general principle of societal evolution (Tsebelis, 2002). One could, therefore, speculate that the combination of democratic institutions with checks and balances, on the one hand, and relatively risk seeking politicians acting within this political system, on the other, is a basis for the success of democratic societies in which bureaucrats who are less willing to take risks than politicians are another means to control risk loving politicians (Thomas et al., 2017).

\section{Conclusion}

Although decision-making under risk is crucial to politics, little is known about the representation of traits that systematically influence decision-making, in particular the risk propensity of voters and politicians. Therefore, we investigated the degree to which political representatives' risk propensity resembles their constituents' risk propensity. Using representative samples of the German Federal Parliament, four German State Parliaments, and the general population of Germany, we show that political representatives are significantly more risk seeking than the average citizen, even when using conservative matching procedures and politically interested citizens as the comparison group. A question not addressed by the present research is how our findings translate to other democratic systems. One hypothesis related to the idea that risk-seeking individuals self-select into politics at disproportionately high levels would suggest crossnational similarities in risk propensity differences between politicians and the general public. However, related lines of research suggest pronounced cross-cultural differences in people's risk attitudes and behaviors, so that our research needs to be extended to other cultural and national contexts.

Aside from these qualifying considerations, our findings point towards a representation gap in the sense that political representatives are more risk seeking than their constituents and, hence, might often take risks their voters would not have taken. From the perspective of descriptive representation, this points at a possible weak spot of current democracies: politicians and citizens do not match on psychological traits that are relevant for (political) decision making. While this is arguably a significant challenge to the principles of (descriptive) representation, we offer a reassuring interpretation of this gap: we argue that a certain proneness for making risky decisions in uncertain environments is downright necessary for good policy and societal evolution, especially considering the inertia caused by the path dependency tendencies of political institutions. Individual politicians might be risk loving and be prepared for risky decisions when they are unavoidable (e. g. in case of war), but they are controlled by a "balance of power". So we can conclude with the words of former German Federal President, Walter Scheel: "Nothing happens without risk, but without taking risks, nothing happens." 5

Received: 9 October 2017 Accepted: 9 April 2018

Published online: 29 May 2018

\section{Notes}

1 Caesar cited Menander, a Greek writer (The Principal Fragments, 391, "Be cast the die!”). According to Plutarch (Life of Pompey, 60.2.9 http://penelope.uchicago.edu/ Thayer/E/Roman/Texts/Plutarch/Lives/Caesar*.html) Caesar gave the quote in the Greek language ("anerriphtho kybos") and mentioned the riskiness: "But finally, with a sort of passion, as if abandoning calculation and casting himself upon the future, and uttering the phrase with which men usually prelude their plunge into desperate and daring fortunes, Let the die be cast." (Plutarch, The Life of Julius Caesar, 32.8.4 http:// penelope.uchicago.edu/Thayer/E/Roman/Texts/Plutarch/Lives/Pompey ${ }^{\star}$.html). The more popular translation "the die is cast" (alea iacta est, Suetonius, Divus Julius 32,1) is misleading (e.g., Pöppelmann 2009, pp 13-14). Nothing was settled, the future was open and uncertain. Lewis and Short (1879, entry: ālěa) give the right translation of the Greek sentence: "Jacta alea esto". Which they translate in English as "Let the dice be cast! Let the game be ventured!"

2 The Richard Nixon Foundation. Download from http://blog.nixonfoundation.org/ 2011/04/the-quotable-richard-nixon/

3 www.brainyquote.com/quotes/quotes/m/markzucker453450.html

4 For a very first descriptive analysis of the data, see Hess et al. (2013).

5 http://www.nur-zitate.com/autor/Walter_Scheel

\section{References}

Anderson C, Galinsky A (2006) Power, optimism, and risk-taking. Eur J Soc Psychol 36(4):511-536

Boettcher WA (2004) The prospects for prospect theory: an empirical evaluation of international relations applications of framing and loss aversion. Political Psychol 25(3):331-362

Boholm A, Corvellec H (2010) A relational theory of risk. J Risk Res 14(2):175-90

Bonin H, Dohmen D, Falk A, Huffman D, Sunde U (2007) Cross sectional earning risk and occupational sorting: the role of risk attitudes. Labor Econ 14:926-937

Brown S, Dietrich M, Ortiz-Nuñez A, Taylor K (2011) Self-employment and attitudes towards risk: timing and unobserved heterogeneity. J Econ Psychol 32:425-433

Caliendo M, Fossen F, Kritikos A (2010) The impact of risk attitudes on entrepreneurial survival. J Econ Behav Organ 67:45-63

Caprara GV, Barbaranelli C, Consiglio C, Picconi L, Zimbardo PG (2003) Personalities of politicians and voters: Unique and synergistic relationships. J Personal Social Psychol 84(4):849-856

Coppola M (2014) Eliciting risk-preferences in socio-economic surveys: how do different measures perform? J Socio Econ 48:1-10

Da Silva S (2014) Risk seekers may be antisocial after all. Clin Exp Med Sci 2 (3):87-95

Dal Bó E, Finan F, Folke O, Persson T, Rickne J (2017) Who becomes a politician?. Quat J Econ 132(4):1877-1914

Derue DS, Nahrgang J, Wellman N, Humphrey S (2011) Trait and behavioral theories of leadership: an integration and meta-analytic test of their relative validity. Pers Psychol 64:7-52

Dohmen T, Falk A, Huffman D, Sunde U (2012) The intergenerational transmission of risk and trust attitude. Rev Econ Stud 79(2):645-677

Dohmen T, Falk A, Huffmann D, Sunde U, Schupp J, Wagner G (2011) Individual risk attitudes. measurement, determinates and behavioral consequences. J Eur Econ Assoc 9(3):522-550

Fehrler S, Fischbacher U, Schneider MT (2016) Who runs? Honesty and selfselection into politics. IZA Discussion Paper No. 10258. https://ssrn.com/ abstract $=2849743$

Frey R, Pedroni A, Mata R, Rieskamp J, Hertwig R (2017) Risk preference shares the psychometric structure of major psychological traits. Sci Adv 3:e1701381

Griffiths AP, Wollheim R (1960) How can one person represent another? Proc Aristot Soc Suppl Vol 34:187-224

Hartley J (2014) Can political leadership be taught? In: Rhodes RA, t'Hart P (eds) The Oxford Handbook of Political Leadership. Oxford University Press, New York, pp 673-690

Headey B (1974) British cabinet ministers: the roles of politicians in executive office. Alden Press, Oxford

Headey B, Muffels R, Wagner GG (2010) Long-running German panel survey shows that personal and economic choices, not just genes, matter for happiness. Proc Natl Acad Sci USA 107:17922-17926

Hermann M (2014) Political Psychology and the Study of Political Leadership. In: Rhodes RA, Hart P (eds) The OxfordHandbook of Political Leadership. Oxford University Press, New York, pp 117-131

Hess M, von Scheve C, Schupp J, Wagner GG (2013) Volksvertreter sind risikofreudiger als das Volk. Wochenber DIW Berl 80:17-21

Iacus SM, King G, Porro G (2009) CEM: coarsened exact matching software. J Stat Softw 30

Iacus SM, King G, Porro G (2011) Causal inference without balance checking: coarsened exact matching. Polit Anal 20(1):1-14 
Josef AK, Richter D, Samanez-Larkin GR, Wagner GG, Hertwig R, Mata R (2016) Stability and change in risk-taking propensity across the adult lifespan. J Personal Social Psychol 111:430-450. https://doi.org/10.1037/pspp0000090

Kahneman D, Tversky A (1979) Prospect theory: an analysis of decision under risk. Econometrica 47(2):263-91

Kam CD (2012) Risk attitudes and political participation. Am J Polit Sci 56 (4):817-836

Keller JW, Foster DM (2012) Presidential leadership style and the political use of force. Polit Psychol 33(5):581-598

Kowert PA, Hermann MG (1997) Who takes risks? daring and caution in foreign policy making. J Confl Resolut 41(5):611-637

Kugler T, Kausel EE, Kocher MG (2012) Are group more rational than individuals? a review of interactive decision making in groups. Wiley Interdiscip Rev 3 (4):471-482

Levy JS (2003) Applications of prospect theory to political science. Synthese 135 (2):215-41

Lewis CT, Short C (1879) A Latin Dictionary. Founded on Andrews' edition of Freund's Latin dictionary. In: Charlton TL, Short C (eds) Revised, enlarged, and in great part. Clarendon Press, Oxford

Mansbridge J (1999) Should blacks represent blacks and women represent women? a contingent "yes". J Polit 61(3):628-657

Mansbridge J (2003) Rethinking representation. Am Polit Sci Rev 97(04):515-528

Martin D (2016) individual risk attitudes and democratic representation. Dissertation, University of Michigan

Mercer J (2005) Prospect theory and political science. Annu Rev Polit Sci 8:1-21

Mintz A, DeRouen K (2010) Understanding foreign policy decision making. Cambridge University Press, New York

Nosic A, Weber M (2010) How riskily do i invest? The role of risk attitudes, risk perceptions, and overconfidence. Decis Anal 7(3):282-301

Phillips A (1995) The politics of presence. Oxford University Press, Oxford

Pitkin HF (1967) The concepts of representation. University of California Press, Berkeley

Pöppelmann C (2009) Nomen est omen. Compact Verlag, Munich

Roe BE, Tilley MR, Gu HH, Beversdorf DQ, Sadee W, Haab TC, Papp AC (2009) Financial and Psychological Risk Attitudes Associated with Two Single Nucleotide Polymorphisms in the Nicotine Receptor (CHRNA4) Gene. PLoS One 4(8):e6704

Sapienza P, Zingales L, Meastripieri D (2009) Gender differences in financial risk aversion and career choices are affected by testosterone. Proc Natl Acad Sci USA 106:15268-15273

Sheffer L, Lowen P, Soroka S, Walgrave S, Sheafer T (2017) Non-representative representatives: an experimental study of the decision making of elected politicians. Am Polit Sci Rev 1-20. https://doi.org/10.1017/S0003055417000569

Sitkins SB, Weingart LR (1995) Determinants of risky decision-making behavior: a test of the mediating role of risk perceptions and propensity. Acad Manag J 38(6):1573-1592

Sutter M (2009) Individual behavior and group membership: comment. Am Econ Rev 99(5):2247-57

Thomas T, Hess M, Wagner GG (2017) Reluctant to reform? A note on risk loving of politicians and bureaucrats. Rev Econ 68:167-179

Tsebelis G (2002) Veto players: how political institutions work. Princeton University Press, Princeton

van den Bos W, Hertwig R (2017) Adolescents display distinctive tolerance to ambiguity and to uncertainty during risky decision making. Sci Rep 7:40962. https://doi.org/10.1038/srep40962

Wagner GG, Frick JR, Schupp J (2007) The German socio-economic panel study (SOEP)-Scope, Evolution and Enhancements. Schmollers Jahrb 127:161-91
Weber EU, Hsee CK (1998) Cross-cultural differences in risk perception but crosscultural similarities in attitudes towards risk. Manag Sci 44:1205-12 17

Weber Max (1919) Politics as a vocation. Verlag von Duncker \& Humblot, München und Leipzig

Weber EU, Milliman R (1997) Perceived risk attitudes: relating risk perception to risky choice. Manag Sci 43:122-143

Weinberg A, Cooper C (2003) Stress among national politicians elected to Parliament for the first time. Stress Health 19(2):111-117

Weinberg AM (1972) Science and trans science. Minerva 10:219-222

Winter DG (2002) Motivation and political leadership. In: Valenty L, Feldman O (eds) Political leadership for the new century: personality and behavior among American leaders. Praeger, Westport, pp 25-47

Wolff C (2013) Functional representation and democracy in the EU. ECPR Press, Colchester

Yechiam E, Ert E (2011) Risk attitude in decision making: search for trait like constructs. Top Cogn Sci 3:166-186

Zuckerman M, Kuhlman DM (2000) Personality and risk-taking: common biosocial factors. J Pers 68(6):999-1029

\section{Data availability}

The dataset on the members of parliaments generated and analyzed during the current study are available from the corresponding author on reasonable request. The SOEP datasets analyzed during the current study are available via the research data center of the SOEP at the German Institute for Economic Research, DIW Berlin, http://www.diw.de/ en/diw_02.c.221178.en/about_soep.html

\section{Additional information}

Supplementary information: accompanies this paper at https://doi.org/10.1057/s41599 018-0112-x.

Competing interests: The authors declare no competing interests.

Reprints and permission information is available online at http://www.nature.com/ reprints

Publisher's note: Springer Nature remains neutral with regard to jurisdictional claims in published maps and institutional affiliations.

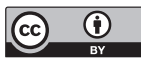

Open Access This article is licensed under a Creative Commons Attribution 4.0 International License, which permits use, sharing, adaptation, distribution and reproduction in any medium or format, as long as you give appropriate credit to the original author(s) and the source, provide a link to the Creative Commons license, and indicate if changes were made. The images or other third party material in this article are included in the article's Creative Commons license, unless indicated otherwise in a credit line to the material. If material is not included in the article's Creative Commons license and your intended use is not permitted by statutory regulation or exceeds the permitted use, you will need to obtain permission directly from the copyright holder. To view a copy of this license, visit http://creativecommons.org/ licenses/by/4.0/

(C) The Author(s) 2018 